The Nova Scotia Section has recently published a brochure on the St. Mary's River Forestry-Wildlife Project. In view of the significance of the project and its successful implementation, the text is being reprinted in The Forestry Chronicle. Additional information on combining forestry and wildlife goals can be found in the document, Forest/Wildlife Guidelines and Standards for Nova Scotia, produced by the N.S. Department of Lands and Forests. Additional information on the St. Mary's River Project can be obtained by writing to the project office, c/o N.S. Department of Lands and Forests, 11 James St., Antigonish, N.S., B2G 1R6.

\section{What it is}

Wise management of Nova Scotia's forest and wildlife resources requires communication and co-operation among many people. The St. Mary's River Forestry-Wildlife Project (SMRP) is a working example of this process involving federal and provincial governments, industry, and nongovernment organizations. Its objective is to combine wildlife habitat management with forestry management and operations. The project builds on the information contained in the provincial publication, Forest/Wildlife Guidelines and Standards for Nova Scotia. Joint studies and trials are conducted to answer specific questions and develop practical and effective methods for managing wildlife and forestry together.

\section{Who is Involved}

The SMRP is a co-operative program of the Canadian Institute of Forestry/Institute Forestier du Canada (CIF/IFC). The project is directed by a committee made up of members from CIF/IFC; the Wildlife, Reforestation and Silviculture, Operations, and Extension Divisions of the N.S. Department of Lands and Forests; Forestry Canada; Department of Fisheries and Oceans (DFO); Scott Maritimes Limited; Stora Forest Industries Limited; St. Mary's River Association; and Wildlife Habitat Canada. The committee meets regularly to discuss research, education and funding needs, and to coordinate activities among the participating agencies. Two biologists and one technician are employed full-time with the project.

\section{Management and Education}

One of the most important goals of the SMRP is to provide an opportunity for people involved in forestry and wildlife to exchange information and learn about each other's work. The SMRP asks advice from forest workers, contractors, and forestry and wildlife planners. Workshops and field discussions identify practical problems and provide an opportunity for wildlife and forestry personnel to express and discuss their opinions on combining wildlife and forestry goals. Everyone takes an active role to develop realistic and economical methods. We believe this approach encourages a more rapid acceptance of new methods into current forestry practices.

The project also produces reports on field research, fact sheets, and training videos on operational methods and proce- dures. Talks are given to familiarize other community and professional groups about the project and its results.

\section{Topics of Study}

\section{A. Special Management Zones (SMZs) along Waterways}

The area along a lakeshore or streambank requires special management as it offers important and fragile wildlife habitats. The water, food, and cover found here is used by many species of wildlife; including fish, amphibians, waterfowl, and mammals. Many wildlife species also use these areas as travel lanes or corridors. Forestry operations are permitted within the SMZ but must follow provincial guidelines. Workshops and early studies have identified particular SMZ topics requiring more information and operational techniques.

1. Stream Crossings. Many small feeder streams found on sites being harveted do not flow during dry periods. In many cases it is not economical or practical to install permanent bridges or culverts. However, silt can be carried long distances and enter larger waterways during periods of heavy rainfall. This silt can destroy spawning beds used by trout and salmon. The SMRP is testing methods to approach and cross small streams using temporary bridges. Workshops have been held with contractors and machine operators to include their advice with the research, and to increase their awareness at possible problem sites.

2. Fish Habitat Improvement. Places to hide and proper water temperatures are important for trout and salmon to survive. Overheating of the water can often be prevented by leaving enough shade trees. Many of our streams have enough shade but lack hiding cover and overheat due to very low water levels during summer. Forest industry personnel believe there is an opportunity for them to improve fish habitat in streams along which they are working, provided this work can be conducted quickly and economically. The SMRP is conducting trials with industry and the Habitat Planning Division of DFO to improve fish habitat with structures made of materials such as rocks and logs that can be found on site. Structures are being tested for their ability to improve instream cover for fish by (1) narrowing and deepening the flow during low water conditions, (2) digging pools, and (3) undercutting banks. Narrowing and deepening the water flow will also help reduce the chance of water overheating, since less water surface is exposed to warm air temperatures.

3. Wildlife Travel Lanes. The vegetation left uncut along lakes and streams provides shelter for many animals which live in or travel in these areas. Little information is available for north-eastern North America on how wide these areas must be to maintain or improve their use by wildlife. Forestry and wildlife personnel need more information in order to make sound recommendations on the width of the corridor to be left before cutting occurs. Wildlife and plant surveys are being carried out by the SMRP to identify habitat differences and wildlife use along streams with uncut strips of different widths. 


\section{B. Wildlife and Forest Habitat Relationships}

Wildlife and forest managers practicing habitat management together need to be able to predict how wildlife will respond to various forestry operations. The SMRP is examining how groups of wildlife such as songbirds, mice, and amphibians respond to vegetation changes on sites where different forestry operations such as cutting, spacing, and planting have occurred.

A long term objective is to begin studies on how the arrangement or spacing of different habitat or forest types affects wildlife species such as deer, moose, and other large mammals. This knowledge could be used by the forest industry when planning operations on large forest blocks.

\section{Snags and Cavity Trees}

Snags or cavity trees are old, dead, or partly dead trees. These are important to about one-quarter of the nearly 250 wildlife species that breed in Nova Scotia. Wild animals often use these trees for nesting, denning, roosting, feeding and perching.

Snags and cavity trees have usually been cut during harvest operations for safety and economic reasons. Forest and wild- life managers are working to ensure enough of these trees are available for wildlife use for many years. Important considerations include: how many trees, what size, where to place them, and how long they last. The SMRP is developing fact sheets to help industry personnel select the best trees to be left for use as snags and cavity trees. A workshop with contractors and woods workers was held to seek their advice about where these trees should be placed for safety and economic reasons.

\section{Field Demonstrations}

Is management for both wildlife and forestry a realistic goal? Forestry managers believe that demonstration areas showing the results of proper operating techniques and management will serve as valuable educational tools. Project staff and NSDLF's regional biologist are working with Scott Maritimes Limited and Stora Forest Industries Limited on three blocks of land to plan harvesting activities and wildlife habitat requirements. These demonstration areas will help forestry contractors, planners, cutters, biologists, foresters, and forestry technicians become more familiar with the goals and techniques of forestry and wildlife management, and current guidelines and standards.

\section{Individual Sustaining Members 1990-91}

\begin{tabular}{llll}
\hline P.W. Ackhurst & VA & E.L. Hughes & MR \\
A. Brookman Anderson & VA & C. Allen Jeffrey & MB \\
H.W. Beall & OV & A. Kabzems & VI \\
A. Bickerstaff & OV & A.J. Kayll & NW \\
J.W. Bird & MR & Nenad Kontic & SN \\
M.P.M. Broeren & D.D. Lockhart & OV \\
George Brown & PA & J.D. MacArthur & CH \\
Brian Cardwell & SO & J.C. MacLeod & OV \\
Kevin M. Carvill & PO Masterson & SO \\
J.H. Cayford & VA & F. Matte & CH \\
T.M. Charles & OV & Monty M. Mosher & VI \\
R.L.P. Clifford & VA & V.J. Nordin & OV \\
J.D. Coats & VI & H.A. Peacock & OV \\
Jay H. Cravens & SO & D.R. Redmond & OV \\
G.W.I. Creighton & F.C. Robinson & SO \\
E.S. Fellows & UN & J.H.G. Smith & VA \\
R.E. Foster & J.O. Smith & AL \\
C.H. Gairns & MR & R.H. Spurway & MR \\
J.A.F. Gardner & VA & R.G. Steele & VI \\
G.J. Garner & CR & A.M.D. Todd & CR \\
Claude Godbout & D.G. Tomlin & OV \\
W. Ross Grinnell & VA & J.R. Walton & VI \\
D.K. Haley & LW & Arden Whidden & NS \\
R.D. Hallett & OR & J.R.M. Williams & SO \\
D.L. Handley & SO & D.R. Young & CO \\
G.A. Hubert & VI & Victor Zsilinsky & SO
\end{tabular}

